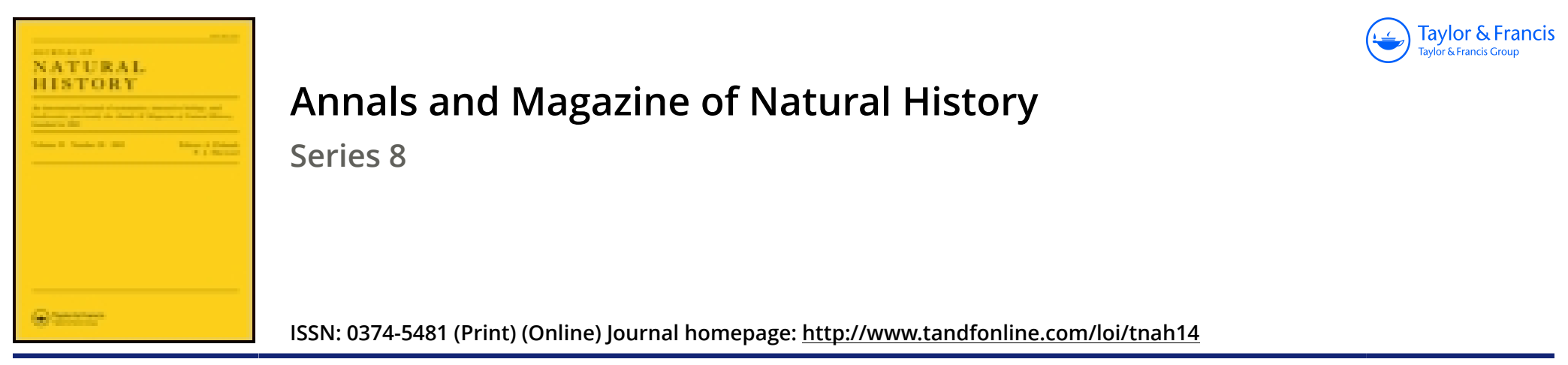

\title{
XVII.-Descriptions of some new species of Heterocera from East and West Africa and tropical South America
}

\section{Herbert Druce F.L.S.}

To cite this article: Herbert Druce F.L.S. (1910) XVII._-Descriptions of some new species of Heterocera from East and West Africa and tropical South America , Annals and Magazine of Natural History, 6:32, 168-183, DOI: 10.1080/00222931008692836

To link to this article: http://dx.doi.org/10.1080/00222931008692836

曲 Published online: 08 Sep 2009.

Submit your article to this journal $\pi$

Џll Article views: 3

Q View related articles $₫$

7 Citing articles: 1 View citing articles 
Euryglossa chrysoceras, Ckll., and E. subsericea, Ckll.

A male $E$. chrysoceras comes from The Ridges, Mackay, Queensland, at flowers of Leptospermum, Oct. 1898 (Turner, 702). British Museum. At the same flowers were taken fomales of $E$. subsericea, Ckll, and these also bear the number 702 , being evidently considered conspecific with chrysoceras. The two insects are so different that it seems improbable that they can be sexes of one, and, moreover, I believe the true male of $E$. subsericea to be 'Turner's $1 a$, taken in some numbers at flowers of Leptospermum, at the same locality, Sept. and Oct. 1898. This insect has every appearance of $E$. subsericea, except for the usual sexual differences and the fact that the head and thorax are dark green instead of black. A very characteristic feature, seen in both sexes, is the dull minutely sculptured front, abruptly contrasting with the shining strongly punctured vertex. The abdomen of the male is shining, in the female it is dull. The venation varies, the first r. n. sometimes squarely meeting the first t.-c. 'The male (Turner's $1 a$ ) is the insect mertioned by Baker ('Invertebrata Pacifica,' May 1906, p. 141) as stilpnosoma turneri. Prof. Baker has kindly sent me his specimen, which proves to be from Mackay, Sept. 1898, collected by L'urner, the name $S$. turneri being a manuscript one by Friese.

XVII.-Descriptions of some new Species of Heterocera from East and West Africa and Tropical South America. By Herbert Druce, F.L.S. \&c.

\section{Fam. Agaristidø.}

Copidryas peruviana, sp. $\mathrm{n}$.

Male.-Head, collar, tegulæ, and thorax brown, thickly irrorated with grey hairs; antennæ and palpi black; abdomen yellow, with a black tuft of hairs at the base, the underside greyish yellow, the legs yellow. Primaries pale brown, thickly mrorated with white and greerish-coloured scales; two zigzag black lines cross the wing beyond the cell from the costal to the inner margin; a small brown spot in the cell; the inner margin brown from the base to the anal angle; the fringe alternately brown and white: secondaries chrome-yellow, bordered with black from the apex almost to the anal angle; 
the fringe alternately black and grey. Underside of both wings pale yellow, irrorated with brown scales : primaries with a black dot at the end of the cell, and beyond a broken black bar that does not reach either margin, the apex and outer margin brown.-Female the same as the male, but rather darker in colour.

Expa:ise $2 \frac{3}{4}$ inches.

Ilab. S.E. Peru, Santo Domingo, 6000 feet, wet season (G. Uckenden, Mus. Druce).

\section{Tuerta rema, sp. n.}

Male.-Head, palpi, and antennæ black, the base of the antennæ white; collar, tegulæ, and thorax reddish brown, thickly irrorated with white hairs; abdomen pale yellow. Primaries: the costal half of the wing from the base to beyond the cell white, the outer half of the cell pale green ; a reddish-brown band extends from the apex to the anal angle and along the inner margin to the base of the wing thickly irrorated with white scales, the inner side of the brown band broadly olive-green, the outer margin and fringe white: secondaries pale yellow, the fringe white; a small black line close to the anal angle. Underside of both wings uniformly pale yellow.

Expanse $1 \frac{1}{2}$ inch.

Hab. German East Africa (Mus. Druce).

\section{Fam. Arctidæ.}

\section{Eiacrisia pales, sp. $\mathrm{n}$.}

Male-Head, collar, tegula, and front of the thorax orange-yellow, the thorax and basal part of the abdomen pale yellow, antennze and legs black, the abdomen black, the anus yellow. Primaries pale yellow: secondaries yellowish white, darkest along the inner margin.-The female the same as the male.

Eixpanse $1 \frac{3}{4}$ inch.

Hab. German East Africa (Mus. Druce).

Allied to Diacrisia lurida, Druce.

\section{Lophocampa dissimilis, sp. n.}

Male and female.-Head chrome-yellow ; palpi and antennæ black; collar white, edged with chrome-yellow; tegulæ chrome-yellow, edged with white; thorax and abdomen black, some yellowish-brown hairs at the base of the 
thorax, abdomen spotted with yellow on the upper side and sides, the two anal segments, the anus, and underside yellowish white; the legs black. Primaries sordid white, the apex and part of the outer margin clouded with pale brown, the veins and $a$ bar at the end of the cell pale brown, the fringe greyish white: secondaries similar to the primaries, but more dusky on the inner margin.

Expanse, $\delta 2, \& 2 \frac{3}{4}$ inches.

Hab. Peru, Chanchamayo, 1000 to 1500 metres (Mus. Druce).

This species is allied to Lophocampa humosa, Dogn., from Ecuador.

\section{Pericopis imitata, sp. $\mathrm{n}$.}

Male-Head, antennæ, collar, thorax, base of the abdomen, and legs black; two yellow spots at the back of the head and two at the base of the primaries; abdomen black, with a row of bluish-grey spots on each side, below which on the sides a row of very minute white dots; the underside spotted with yellow; the anal tuft bright red. Primaries very similar to those of $P$. arema, Boisd., but browner and not so hyaline, without the broad black band across the wing at the end of the cell as in $P$. arema; a faint marginal zigzag line extends from the apex to the anal angle; the fringe black : secondaries pale yellowish white, very broadly bordered with black at the end of the cell; two yellowishwhite spots; a marginal row of white spots from near the apex to the anal angle. The underside very similar to the upperside, a red spot at the base of both wings.

Expanse, of o, 3 inches.

Hab. Peru, Limbani, Carabaya, 9500 feet, 3 o , 1 . $q$; Rio Huacamayo, 3100 feet, 2 d; Oconeque, 7000 feet, 1 d; Aqualani, 10,000 feet, 4 o (G. Ockenden). Brazil, 1 के (ex Staudinger, Mus. Druce).

Near P. arema, Boisd., but at once distinguished from that species by the bluish-grey sides to the abdomen.

\section{Pericopis titan, sp. n.}

Female--Head, antennæ, palpi, collar, tegulæ, thorax, abdomen, and legs all black; collar spotted with white; a yellow spot at the base of the tegula; the sides of the abdomen greenish grey, with a row of white dots below the underside yellow. Primaries blackish grey, marked with black very much the same as Pericopis imitata, Druce : secondaries white, broadly bordered with black; two white spots just 
beyond the cell; the veins black; a marginal row of rather large white spots extends from the apex to the anal angle. Underside similar to the upperside; a large red spot at the base of both wings and a white spot on each side of the thorax.

Expanse 3 inches.

Hab. Peru, Chanchamayo, 1000 to 1500 metres (Mus. Druce).

\section{Pericopis palmeri, sp. n.}

Male.-Head, antennæ, collar, tegulæ, thorax, and legs black; tegulæ edged with yellow; abdomen black; a row of large yellow spots on both sides; the underside yellow; anal tuft red. Primaries dark brown; a red spot at the base; a yellow streak on the inner margin; the semihyaline markings very similar to those of Pericopis imitata, Druce, but mostly edged with yellow; the spot in the cell extends to the base ; a fine submarginal yellow line extends from the apex to the anal angle; the fringe dark brown: secondaries white, the veins and a bar at the end of the cell black; the outer margin broadly black, with a row of red spots from the apex to the anal angle and a marginal row of white dots also from the apex to the anal angle. Underside: primaries the same as above, but with several reddish marks along the outer margin : secondaries similar to the upperside, the costal margin red.-Female. Head, antennæ, collar, tegulæ, and thorax black; abdomen the same as the male. Primaries brown, the markings much more indistinct: secondaries pale yellow, very broadly bordered with black; a yellow spot at the end of the cell; the costal margin red; the marginal red and white spots the same as the male; the fringe black. Underside: primaries very similar to the upperside, but much paler in colour: secondaries the same as the upperside, with all the red markings very bright in colour; the white row of marginal spots are larger and more distinct.

Expanse, $\delta 2 \frac{3}{4}$, $93 \frac{1}{2}$ inches.

Hab. West Colombia, San Antonio, 5800 feet. (G. $M$. Pulmer) ; East Peru, Puzuzo (J. Egg, 2000-4000 feet, Mus. Druce).

\section{Pericopis damon, sp. n.}

Female. - Head, antennæ, collar, tegulæe, and thorax black, the head, collar, and tegulæ spotted with white; abdomen black above, yellowish white on the anderside; legs black. Primaries dusky hyaline, the apex, outer and inner 
margin broadly black; two black bands cross the wing, that nearest the base from the costal to the inner margin; the band at the end of the cell from the costal to the outer margin; the veins all black: secondaries yellowish hyaline, broadly bordered with black from the apex to the anal angle; a marginal row of rather large white spots extends from the apex to the anal angle; a black band crosses the wing at the end of the cell from the costal $t_{1}$ about the middle of the outer margin; the veins and fringe black. Underside very similar to the upperside, but slightly more yellow in tone.

Expanse $3 \frac{1}{2}$ inches.

Hab. Peru, Chanchamayo, 1000-1500 metres (Mus. Druce).

\section{Pericopis semirufa, sp. $\mathrm{n}$.}

Female.-Head and antennæ black, head spotted with white; collar black, spotted wirh yellow; tegulæ black, with a yellow spot at the base; thorax brownish black; abdomen reddish brown, yellow on the underside; legs black. Primaries brownish hyaline, the costal margin, apex, outer and inner margin, and two bands crossing the wing all black: secondaries reddish hyaline, the onter margin black, with a marginal row of white spots extending from the apex to the anal angle; above the black margin a red band extends from the apex to the anal angle; the fringe black. Underside very similar to the upperside; primaries with a red band at the apex and a reddish spot above the anal angle; secondaries with the costal margin red.

Expanse $3 \frac{3}{4}$ inches.

Hab. Peru, Chanchamayo, 1000-1500 metres (Mus. Druce).

Pericopis sylvia, sp. n.

Female.-Head, palpi, antennæ, collar, tegulæe, and thorax black, collar and tegulæ spotted with white; abdomen grey, the sides black; the underside pale yellow; legs black. Primaries greyish hyaline, the costal margin, apex, outer and inner margin black; a reddish-brown line extends along the inner margin from the base nearly to the apex; a black band crosses the wing about the middle of the cell from the costal to the inner margin; a black band at the end of the cell, a few white dots at the apex, and several indistinct brown spots on the inner side of the white dots: secondaries semihyaline white, the veins and a bar at the end of the cell black; the outer margin broadly black from the apex to the anal angle, 
and a marginal row of rather large white spots. Underside very similar to the upperside, but with the costal margin of the secondaries from the base almost to the apex chromeyellow.

Expanse $3 \frac{1}{2}$ inches.

Hab. Peru, Chanchamayo, 1000-1500 metres (Mus. Druce).

\section{Pericopis madana, sp. n.}

Female.-Head, palpi, antennæ, collar, tegulæ, thorax, and abdomen black, the collar spotted with white, abdomen with a bluish-grey band on each side; the underside pale yellow; legs black. Primaries brownish grey, the apex, inner margin, and two bands crossing the wings all black ; several small white spots at the apex, below which are some indistinet reddish-brown spots, also two reddisb-brown spots close to the anal angle; a bright red spot at the base : secondaries white, the veins all black; the inner half of the wing thickly clothed with black hairs; the outer margin broadly bordered with black, with a submarginal row of indistinct reddish spots and a marginal row of white spots extending from the apex to the anal angle; the fringe black. Underside similar to the upperside, but with nearly all the black markings red.

Expanse 3 inches.

$H a b$. West Colombia, San Antonio, 5800 feet (G. $M$. Palmer, Mus. Druce).

A very distinct species, quite unlike any other known to me.

\section{Pericopis hodeva, sp. n.}

Female.-Head, antennæ, collar, tegulæ, thorax, and legs all black; collar spotted with yellow, tegulæe edged with reddish brown; aldomen above reddish brown, with a central black line down the middle from the base to the anus; a double black line on each side; the underside pale yellow; the anal segment bluish grey. Primaries: the apical third of the wing black, from the end of the cell to the base brownish yellow, clouded in the cell and along the inner margin with brown; the veins black; the fringe black; a yellow line at the end of the cell; secondaries black, yellowish brown at the apex and half round the outer margin. Underside very similar to the upperside, but brighter in colour, and a distinct black spot about the middle of the cell on the primaries.

Expanse $3 \frac{1}{2}$ inches.

Ilab. Peru, Puzuzo (Mus. Druce). 
Pericopis rhea, sp. n.

Fenale.-Head, palpi, antennæ, collar, and tegulæ black, collar spotted with yellow; thorax yellowish brown, clothed with some black hairs; abdomen yellowish brown, with a central black line from the base to the anus; a narrow black line on each side; the underside pale yellow. Primaries : the apical third of the wing brownish black, the other two-thirds of the wing dark orange-yellow, the veins black; a black bar at the end of the cell and an ill-defined black band crossing the wing from the costal margin to the upperside of vein 2 ; the fringe black: secondaries dark orange-yellow, the outer margin and a wide band partly across the middle of the wing: below the cell black. Underside very similar to the upperside, but brighter in colour.

Expanse $3 \frac{3}{4}$ inches.

Hab. Peru, Pachitea (Mus. Druce).

\section{Pericopis staudingeri, sp. $\mathrm{n}$.}

Female.-Head, palpi, antennæ, collar, tegulæ, and thorax black, head and tegulæ spotted with white; abdomen red, with a central black band extending from the base to the anus ; a black band on each side; the underside yellow ; legs black. Primaries brownish black, crossed from the costal margin nearest the apex to the anal angle by a cream-coloured wide band; a black bar at the end of the cell : secondaries bright red, the outer margin black from the apex to the anal angle; a broken black band crosses the wing below the middle. Underside very similar to the upperside, with the inner margin of the primaries yellowish brown; the secondaries with a large round yellow spot at the end of the cell.

Expanse $3 \frac{1}{2}$ inches.

$H a b$. Peru, Cuzco (received from the late Dr. Staudinger); S.E. Peru, Santo Domingo, 6000 feet ( $G$. Ockenden, Mus. Druce).

\section{Pericopis buckleyi, sp. $\mathrm{n}$.}

Female-Head, palpi, antennæ, collar, tegulæ, thorax,. abdomen, and legs black. Primaries dark brown, darkest at the base; a red spot on the costal margin close to the base; the fringe dark brown: secondaries black, three pale yellow spots between veins 5,6 , and 7 near the apex; a rosecoloured band extending from the anal angle to vein 4 ; the 
fringe black. 'The underside the same as the uppersile: the secondaries with a red spot at the base.

Expanse 4 inches.

Hab. Ecuador, Sarayacu (C. Buckley, Mus. Druce).

\section{Pericopis salome, sp. n.}

Female.-Head, palpi, antennæ, collar, tegulæ, thorax, abdomen, and legs black. Primaries dark brown, very similar to Pericopis rosena, Butler : secondaries black; a yellow spot at the end of the cell and one beyond nearest the apex; a wide rose-coloured band extends from the inner margin to the cell, the outer margin of the band broken into streaks; the fringe black. Underside of the primaries dark brown; four pale yellow spots beyond the cell and a pale yellow band from the end of the cell to the inner margin above the apex : secondaries the same as above, but browner in colour.

Expanse $2 \frac{1}{2}$ inches.

Hab. Ecuador (C. Buckley, Mus. Druce).

Allied to Pericopis rosina, Butler, Lep. Exot. p. 77, t. xxx. fig. 1.

\section{Pericopis unxia, sp. n.}

Male.-Head, palpi, and antennæ black; collar black, with four yellow spots; tegulæ black, with a large yellow spot at the base ; thorax black; abdomen yellow, a central black line extends from the base to the anus, a black line on each side; the underside pale yellow, the anal tuft orange; legs black and yellow. Primaries dusky hyaline, very similar to those of Pericopis sibylla, Butler; a marginal row of small white dots extends from the apex to the anal angle: secondaries very pale yellow, broadly bordered with black; a marginal row of small white dots extending from the apex to the anal angle; a fine black line crosses the wing beyond the cell; an indistinct red line at the apex; the fringe black. Underside very similar to the upperside, but much more yellow in colour; the costal margin of the secondaries reddish brown; a red spot at the base of all the wings.

Expanse $2 \frac{3}{4}$ inches.

Hab. Peru, La Union, Rio Huacamayo, Carabaya, 2000 feet; Santo Domingo, 6000 feet (G. Ockenden, Mus. Druce). 
Fam. Lithosidæ.

Chrysochlorosia superba, sp. $n$.

Male.-Head, collar, tegulæ, thorax, and abdomen metallic green; antennæ metallic green, the tips white; the anus bright metallic blue; the underside of the ablomen reddish; the legs metallic blue-green. Primaries metallic orange-blue and green, broadly bordered with black on the outer margin; the fringe bright metallic blue: secondaries black. Underside of both wings greenish black.

Expanse $1 \frac{1}{4}$ inch.

Hab. Colombia, Rio San Juan, 250 feet (G. M. Palmer, Mus. Druce).

\section{Ptychoglene phobe, sp. n.}

Male.-Head, antennæ, tegulæ, and thorax brownish black; collar white; abdomen black, each segment edged with white; underside of the abdomen white; legs brownish black. Primaries orange-yellow, the costal margin, apex, and outer margin broadly black, the inner margin edged with black; the fringe black: secondaries orange-red, bordered with black from the apex to the anal angle; two black streaks at the base of the wing; the apical half of the fringe black, the anal half orange-red. Underside very similar to the upperside, but paler in colour.

Expanse $1_{10}^{4}$ inch.

Hab. East Peru, Huancabamba, 6000-10,000 feet (Boottger, Mus. Druce).

Fam. Lasiocampidæ.

Chrysopoloma opalina, sp. n.

Male.-Head, collar, tegulæ, thorax, abdomen, and legs pale cream-colour; antennæ pale brown. Primaries pale cream-colour; an indistinct row of brownish-black dots crosses the wing from near the apex to the inner margin close to the anal angle, the spot on the inner margin much the largest: secondaries pale cream-colour, crossed from the apex to the inner margiu by a double row of indistinct black duts, also a marginal row of very indistinct dots extends from the apex to the anal angle; the fringe of both wings pale cream-colour.Female very similar to the male, but much larger, very thinly clothed with scales and quite opalescent; the tips of the antennæ black.

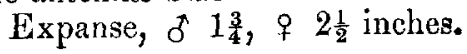


Hab. West Africa, Bitje, Ja River, Cameroons, 2000 feet, dry season (G. L. Bates, Mus. Druce).

Allied to Chrysopoloma subiridescens, Holland, and Chrysopoloma citrina, Druce.

\section{Fam. Limacodidz.}

Dalcera semirufa, sp. $\mathrm{n}$.

Male.-Head, collar, tegulæ, thorax, and abdomen yellow; antennæ and legs black. Primaries red, the costal and outer margin greenish yellow: secondaries yellow, broadly bordered from the apex to the anal angle with black; the fringe yellow. Underside of both wings yellow, broadly bordered with black.

Expanse $1_{2}^{1}$ inch.

Hab. Colombia, Rio San Juan, Chaco, 150 feet (G. M. Palner, Mus. Druce).

Birthama (?) dodona, sp. n.

Male.-Head, collar, tegulæe, thorax, abdomen, and legs chrome-yellow; antennæe and palpi black. Primaries chromeyellow, the veins darker; a straight brown line crosses the wing from the apex to the inner margin close to the base; the fringe brownish yellow : secondaries chrome-yellow, paler than the primaries; the underside of both wings chrome-yellow, entirely without markings.

Expanse 2 inches.

$H a b$. West Africa, Bitje, Ja River, Cameroons, 2000 feet, wet season (G. L. Bates, Mus. Druce).

\section{Fam. Notodontidx.}

Pheosia ockendeni, sp. n.

Male.-Head, collar, tegulæ, and thorax dark grey, mixed with white hairs; palpi black; antemne pale brown; abdomen black, the two anal segments grey, underside of the abdomen yellowish white; legs dark grey. Primaries dark grey, shaded with reddish brown on the costal margin near the apex; a double black line crosses the wing beyond the cell from the costal 10 the inner margin; a second double black line crosses the wing near the base from the costal to the inner margin, the inner margin clouded with black; two reddish-brown spots edged with black at the end of the cell; the marginal line black; fringe grey : secondaries white, the Ann. \& Mag. N. Hisi. Ser. 8. Vol. vi. 
costal margin from the base to the apex blackish grey, the marginal line black; the fringe white. Underside: primaries grey, reddish brown along the costal margin : secondaries white.

Expanse 2 inches.

Hab. North-east Peru, Aqualani, 10,000 feet, wet season (G. Ockenden, Mus. Druce).

Fam. Noctuidæ.

Subfam. ACRONYCTINA.

Erocha trita, sp. n.

Male.-Head, abdomen, and legs black; collar, tegulw, and thorax grey; the anal tuft reddish brown. Primaries grey, very thickly irrorated with black scales; a round black spot in the cell and an oval-shaped spot at the end of the cell; a zigzag rather broad white line crosses the wing near the base from the costal to the inner margin; a second zigzag line crosses the wing beyond the cell, ending in a large whito spot close to the anal angle; the primaries are very similar to those of Erocha dolens, Druce : secondaries pale creamyellow, the marginal line black; the fringe white. Underside similar to the upperside, the costal margin and the apex of the primaries black.

Expanse 2 inches.

Hab. S.E. Peru, Aqualani, 10,000 feet (G. Ockenden, Mus. Druce).

\section{Iscadia buckleyi, sp. n.}

CEdemasia (?) alcimede, Druce, P. Z. \$. 1890, p. 510; Biologia Centr.Am., Lep. Het. ii. p. 453.

Phastia alcimede, Schs. Trans. Ent. Soc. 1891, p. 257.

Female.-Head and palpi black above, underside of palpi pale brown ; collar, tegula, thorax, and abdomen dark brown, underside of the abdomen pale brown. Primaries dark brown, pale brown at the base and partly across the wing; two spots in the cell; two zigzag black lines cross the wing from the costal to the inner margin, the first nearest the base, the second beyond the cell; a pale brown patch at the apex crossed with black spots; a submarginal light brown line with black points extends from apex to the anal angle; the marginal line black; the fringe dark brown: secondaries uniformly brown, the fringe slightly paler in colour. Underside of both wings brown.

Expanse $2 \frac{1}{4}$ inches.

Hab. Ecuador, Sarayacu (Buckley, Mus. Druce). 


\section{Iscadia variegata, sp. $\mathrm{n}$.}

Female.-Head, collar, tegulæ, thorax, and abdomen grey irrorated with black hairs, collar edged with black; antennæ greyish brown; palpi grey, the point black; underside of the abdomen and legs greyish white. Primaries groy, heavily narked with brown along the costal margin; a waved black line crosses the middle of the wing from the costal to the inner margin; an indistinct zigzag white line crosses from near the apex to the anal angle; a marginal row of small black spots extends from the apex to the anal angle; a black spot at the end of the cell; the fringe dark grey : secondaries brownish white, deeply shaded with brown at the apex and partly round the outer margin. Underside: primaries greyish black, the inner margin white: secondaries the same as above.

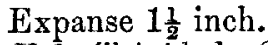

Hab. 'Trinidad, Caparo (S. M. Klages); Colombia, Don Amo, 2000 feet (H. H. Smith) ; S.E. Peru, Santo Domingo, 6000 feet (G. Ockenden, Mus. Druce).

\section{Aloognatha nitescens, sp. $\mathrm{n}$.}

Male--Head, antennæ, collar, tegulæ, thorax, and abdomen very dark grey; the underside of the thorax, legs, and abdomen pale grey. Primaries grey, thickly irrorated with fine black scales; a black spot in the middle of the cell and one at the end of the cell; a dark grey mark near the apex, below which are several black spots; the outer margin spotted with black; the fringe grey : secondaries white, slightly edged with pale brown at the apex; the fringe white. Underside: primaries pale grey, with three black spots on the costal margin near the apox: secondaries as above.Female the sane as the male, but larger and more heavily marked.

Expanse, $\delta 1_{2}^{1}$, $+1_{4}^{3}$ inch.

Hab. Peru, Oconeque, Carabaya, 7000 feet $(G$. Ockenden, Mus. Druce).

\section{Elceognatha melanosticta, sp. $n$.}

Male--Head, collar, tegulæ, and thorax dark grey, the third joint of the palpi black, the base of the thorax mottled with white; abdomen blackish brown, anal tuft white ; underside of the abdomen and legs yellowish white. Primaries grey, the base heavily mottled with white, crossed by several black lines; a submarginal waved pale grey line extends 
from the apex to the anal angle; the marginal line spotted with black : secondaries greyish white, the underside of both wings pale grey.-Female very similar to the male, but darker in colour.

Fxpanse $1 \frac{1}{2}$ inch.

$H a b$. S.E. Peru, La Oroya, Rio Inambari, 3000 feet; Santo Domingo, 6000 feet (G. Ockenden, Mus. Druce).

\section{Eloeognatha purpurascens, sp. n.}

Male.-Head, palpi, antennæ, collar, tegulæ, thorax, and abdomen greyish black, the underside of the abdomen and legs yellowish white. Primaries dark grey ; a small black spot at the base, one in the cell, and one at the end of the cell; a greenish spot on the inner margin close to the base, edged with white; a reddish-brown spot near the apex, streaked with black; a marginal row of small black dots extends from the apex to the anal angle: secondaries brownish white. Underside of both wings pale brown.

Expanse $1 \frac{1}{2}$ inch.

$H a b$. S.E. Peru, Rio Inambari, 3000 feet (G. Ockenden, Mus. Druce).

\section{Elcognatha cacaonis, sp. n.}

Female.-Head, palpi, collar, tegulæ, thorax, and abdomen very dark blackish brown; antennæ black; legs grey. Primaries dark brown, thickly irrorated with white scales and lines; a grey mark on the costal margin close to the base, below which is a black band reaching the inner margin; several white waved lines extend from the apex to the anal angle; the marginal line spotted with black; the fringe brown: secondaries dark blackish brown, the fringe grey. Underside of both wings black.

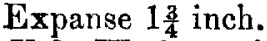

Hab. W. Central Trinidad, Caparo (F. Birch, Mus. Druce).

\section{Fam. Ëgeridm.}

\section{Melittia rugia, sp. n.}

Head, autennæ, tegulæ, thorax, and abdomen black; collar white; palpi white, tipped with black; legs black, clothed with black hairs; the terminal joint clothed with bright red hairs. Primaries bluish black, the cell hyaline, the fringe black : secondaries hyaline, the veins and fringe black, the inner margin from the base to the anal angle thickly 
clothed with metallic bluish-green scales. The underside similar to the upperside.

Expanse 13 inch.

Hab. Peru, Chanchamayo, 1000-1500 metres (Mus. Druce).

$$
\text { Egeria belia, sp. n. }
$$

Male--Head, collar, thorax, and abdomen bluish black, abdomen and thorax white on the underside; antennæ black; palpi black, white on the underside; legs black. Primaries black; a spot at the end of the cell; a band beyond the cell extending from the costal margin to the anal angle, and a streak from the base along tho inner margin all hyaline, the band near the apex crossed by black veins: secondaries liyaline, the veins black, the fringe black.

Expanse $1 \frac{1}{2}$ inch.

Hab. W. Africa, Bitje, Ja River, Cameroons, 2000 feet, wet season (G. L. Bates, Mus. Druce).

\section{Fam. Pyralidæ.}

Subfam. CHRYSAUGINE.

Tamyra klagesi, sp. n.

Female.-Head, collar, tegulæ, and thorax pinkish fawncolour, the tegulæ edged with reddish brown; palpi very long, tufted at the end, black above, fawn-colour on the underside; antennæ reddish brown; abdomen reddish brown; legs brown. Primaries: the costal half of the wing pale fawn-colour, irrorated with minute dark brown scales; the inner half of the wing and the outer margin reddish brown, darkest about the middle of the inner margin; a submarginal black waved line extends from the apex to vein 1 ; the fringe reddish brown: secondaries pinkish white, darkest at the apex and round the outer margin. Underside pinkish white, the apex and onter margin of both wings reddish brown; a black spot at the end of the cell of both wings.

Expanse $2 \frac{1}{4}$ inches.

Hab. 'Trinidad, Caparo (S. M. Klages, Mus. Druce).

Allied to Tamyra penicillana, Herr.-Schäff.

Subfam. EPIPASCHIINAT.

Macalla argentilinea, sp. $\mathrm{n}$.

Male.-Head pale brown, collar and tegulæ white streaked with pale brown; antenna brown; abdomen pale brown, 
spotted with black on each side; legs pale brown. Primaries pale yellowish brown, crossed from the costal to the inner margin by two silvery-white lines, the first near the base, the second at the end of the cell; the lines are edged with black on the inner side; a large oval-shaped white spot, thickly irrorated with pale brown scales on the outer margin close to the anal angle, edged with black, the margiual line black; two black streaks at the apex; the fringe silvery brown: secondaries dusky white, darkest at the apex. Underside brownish white.

Expanse $1 \frac{1}{4}$ inch.

$H a b$. S.E. Peru, Santo Domingo, 6000 feet ( $G$. Ockenden, Mus. Druce).

\section{Macalla viridis, sp. $\mathrm{n}$.}

Male.-Head, palpi, and antennæ pale brown; collar and tegula pale pea-green; thorax and abdomen pale brown. Primaries pea-green, fading to yellowish brown; a silverybrown line crossing the wing from the costal margin to the inner margin close to the base, a second about the middle of cell, which extends partly along the inner margin almost to the anal angle, then crosses the wing to the apex, curves round the end of the cell to just above vein 1 ; a dark ovalshaped mark at the end of the cell, edged with pale brown, the marginal line silvery brown: secondaries silky white. Underside: primaries pale pinkish brown, secondaries white.

Expanse $11^{4}$ inch.

Hab. S.E. Yeru, Santo Domingo, 6000 feet (G. Ockenden, Mus. Druce).

\section{Macalla ruflinea, sp. $\mathrm{n}$.}

Male-Head, thorax, and abdomen grey; collar and tegulæ reddish brown. Primaries grey, thickly irrorated with dark brown scales; five reddish-brown lines cross the wing beyond the cell, forming a network to the outer margin; the fringe alternately reddish brown and grey : secondaries silky white, shaded with blackish brown at the apex. Underside: primaries blackish brown, secondaries as above.-Female very similar to the male, but larger and more heavily marked with reddish-brown lines on the primaries; the secondaries are also blacker round the outer margin.

Expanse, $\delta 1 \frac{3}{10}$, $+1 \frac{1}{2}$ inch.

Hab. S.E. Peru, Santo Domingo, 6000 feet ( $G$. Ockenden, Mus. Druce). 


\section{Macalla rufbasis, $\mathrm{sp} . \mathrm{n}$.}

Male-Head, palpi, collar, tegulæ, and thorax brownish red; antennæ brown; abdomen grey. Primaries dark grey, the basal half brownish red; two waved whitish lines cross the wing from the costal to the inner margin, the first at the end of the cell, the second submarginal; a reddish-brown spot at the apex; the marginal line black; the fringe white: secondaries sordid white, the marginal line black. Underside: primaries pale brown; secondaries the same as above, with the costal margin broadly brown.

Expanse $1 \frac{1}{2}$ inch.

Hab. Peru, Rio Huacamayo, Carabaya, 3100 feet $(A$. Ockenden, Mus. Druce).

\section{Subfam. CRAMBINAT.}

Erupa titana, sp. n.

Male.-Head, palpi, collar, tegulæ, thorax, and abdomen dark brown; underside of the abdomen and legs yellowish brown. Primaries dark glossy brown, crossed from the apex almost to the middle of the inner margin by a waved yellow line; a large yellow >-shaped mark crosses the wing about the middle from the costal to the inner margin; the point of the $>$ is at the end of the cell; a marginal row of black spots with yellow points extends trom the apex to the anal angle; the fringe dark brown: secondaries very dark brown. Underside of both wings glossy dark brown, with a pinkish tinge : primaries, a dark spot at the end of the cell, the costal and outer margin edged with yellow : secondaries, the outer margin edged with yellow and a black spot at the end of the cell.

Expanse $2 \frac{1}{4}$ inches.

Ilab. S.E. Peru, Santo.Domingo, 6000 feet (G. Ockenden, Mus. Druce).

\section{Erupa argentilinea, sp. n.}

Male.-Head, palpi, antennæ, collar, tegulæ, and thorax dark reddish brown; abdomen pale yellow, almost creamcolour. Primaries reddish brown, crossed from the costal to the inner margin by three broken curved silver lines; a marginal row of small silver spots extends from the apex to the anal angle; the fringe reddish brown : secondaries creamcolour, with the outer margin slightly dusky. Underside of both wings pale reddish brown.

Expanse $1 \frac{1}{4}$ inch.

Hab. West Colombia, San Antonio, 5800 feet (M. $G$. Pulmer, Mus. Druce). 